\title{
Statutinių organizacijų darbuotojų subjektyvios gerovės ypatumai
}

\author{
Aistė Diržytė, Aleksandras Patapas, Ustina Fedkovič \\ Mykolo Romerio universitetas \\ Ateities g. 20, LT-08303 Vilnius, Lietuva \\ doi:10.13165/VPA-14-13-2-09
}

\begin{abstract}
Anotacija. Straipsnyje siekiama atskleisti statutiniu organizaciju darbuotoju subjektyvios geroves ypatumus, supažindinama su Lietuvoje atlikto statutiniu organizaciju darbuotoju $(n=120)$ subjektyvios gerovés tyrimo rezultatais. Nors Lietuvoje jau keleta metu intensyviai atliekami ịvairiu tiriamuju grupiu subjektyvios gerovès tyrimai, pavyzdžiui, medicinos darbuotoju, onkologiniu ligoniu, studentu, vis dèlto statutiniu organizaciju darbuotoju psichologine gerove dar nebuvo tyrinèta. Šiame straipsnyje pristatomo tyrimo tikslas - išnagrinèti statutiniu organizaciju darbuotoju subjektyvios gerovès ypatumus, subjektyvios gerovès sasajas su darbuotoju psichologinemis charakteristikomis bei streso ịveika. Tyrimui atlikti naudota Lietuviškoji psichologinès geroves skale (LPGS-S) [2](2013), Eksternalumo - internalumo skale [3] (1988), Streso ịveikos klausimynas [12](2006). Atliktame tyrime buvo gautas pakankamas visu naudotu metodiku vidinis suderinamumas. Tyrimo rezultatai parode, kad daugiausiai statutiniu organizaciju darbuotojai (beveik 46 proc.) pasižymèjo vidutiniu subjektyvios gerovès lygiu. Nustatyta, kad subjektyvi gerovè statistiškai reikšmingai teigiamai susijusi su vidiniu kontrolès lokusu, konstruktyviomis pastangomis spręsti problemas. Taip pat nustatyta, kad kuo emocinès iškrovos ịverčiai aukštesni, tuo psichologinès gerovès iverčiai yra žemesni, ir atvirkščiai - kuo prastesnè subjektyvi gerové, tuo didesne emocine iškrova. Statutiniu organizaciju darbuotojai, kurie pasižymi didesniais psichologinès gerovés ịverčiais, siekdami ịveikti stresines situacijas, rečiau ieško kaltuju, kaltina likima ar išlieja susikaupusias neigiamas emocijas ant aplinkinių. Taip pat nustatyta, kad darbuotojai, kurie mažiau tiki, kad patys gali kontroliuoti gyvenimo situacijas, pasiekimus, šeimos santykius, dažniau ị stresa reaguoja vengimu spręsti iškylančias problemas.
\end{abstract}


Raktažodžiai: statutinè organizacija, kontrolès lokusas, streso ịveika, subjektyvi gerove.

Keywords: statutory organization, locus of control, coping, subjective wellbeing.

\section{İvadas}

Šiuo metu Lietuvoje ir kitose šalyse vis daugiau demesio skiriama subjektyvios gerovès tyrimams. Darbuotojų subjektyvia gerove ypatingai susidomèta tuomet, kai Quick, Nelson ir Hurrell [19] apskaičiavo, jog įvairių stresorių ir netinkamų darbo sąlygų pasekmès (sumažèjęs efektyvumas, iniciatyva, motyvacija, pravaikštos dèl sveikatos sutrikimo) JAV organizacijoms kainuoja 100 bilijonų dolerių nuostoliu per metus. Subjektyvios gerovès tyrimų srities tikslas - teikti praktines rekomendacijas, kaip ,pagerinti gyvenimo kokybę darbe, sustiprinti darbuotojų apsaugą ir sukurti visomis prasmėmis sveiką darbo aplinką, nes tik tokioje aplinkoje galimi aukšti pasiekimų rodikliai“" $[19$, p. 45].

Nors Lietuvoje jau keletą metų intensyviai atliekami įvairių tiriamųjų grupių subjektyvios gerovès tyrimai, pavyzdžiui, medicinos darbuotojų, onkologinių ligonių, studentų [1], vis dèlto statutinių organizacijų darbuotojų psichologinė gerové dar nebuvo tyrinèta. Iki šiol daugiausiai buvo tirtas tik patiriamo streso lygis [5], darbinio streso ypatumai [6], streso ịveikos strategijos [20].

Statutinių organizacijų darbuotojų subjektyvios gerovès tyrimai svarbūs todèl, kad, naujausiais moksliniais duomenimis, nuo darbuotojų subjektyvios gerovès priklauso jų darbo efektyvumas [9], o tai reiškia, kad nuo statutinių organizacijų darbuotojų subjektyvios gerovès gali priklausyti ir visuomenès saugumas bei gerovè. Šiame straipsnyje pristatomo tyrimo tikslas - išsiaiškinti statutinių organizacijų darbuotojų subjektyvios gerovės ypatumus, subjektyvios gerovės sąsajas su darbuotojų psichologinėmis charakteristikomis bei streso įveikimo strategijomis.

\section{Metodologija}

\section{Tiriamieji}

Tiriamieji buvo atrinkti patogiosios atrankos būdu, respondentų grupę sudarè policijos pareigūnai, kriminalinės policijos darbuotojai ir operatyviniai darbuotojai. Apklausoje dalyvavo ir ị kiekybinio tyrimo anketos klausimus atsaké iš viso 120 fizinių asmenų. Jauniausiojo respondento amžius -23 , vyriausiojo - 58 metai. Respondentų amžiaus vidurkis - 36 metai. Tiriamųjų grupèje buvo 42 proc. moterų ir 58 proc. vyrų. Didžioji dalis tiriamųjų turejjo aukštajji ( 86,7 proc.), dalis - aukštesniji (13,3 proc.) išsilavinimą. 66,7 proc. respondentų gyvena santuokoje, 25 proc. nesusituokę, 8,3 proc. - išsiskyrę (išsiskyrusios). 


\section{Tyrimo metodai}

Tyrimas buvo atliekamas taikant kiekybinį tyrimo metodą.

Statutinių organizacijų darbuotojų subjektyviai gerovei įvertinti naudota Lietuviška psichologinès gerovès skalè (LPGS-S) [2]. Metodiką sudaro 59 teiginiai, kuriuos prašoma ịvertinti Likerto skalejje nuo atsakymo tikrai ne iki atsakymo tikrai taip. Metodiką sudaro 7 subskalès:

1) Optimizmo (pavyzdžiui, „Optimistiškai žiūriu ị savo ateiț̨‘);

2) Pasitenkinimo pragyvenimo lygiu (pavyzdžiui, „Mano pajamos garantuoja man saugumą");

3) Neigiamo emocingumo nebuvimo (pavyzdžiui, „Manau, kad sugebu kontroliuoti savo jausmus ir elgesį“");

4) Pasitenkinimo bendravimu su artimaisiais (pavyzdžiui, „Mano šeima yra mano ramstis");

5) Pasitenkinimo tarpasmeniniais santykiais (pavyzdžiui, „Esu patenkintas santykiais su draugais");

6) Pasitenkinimo fizine sveikata (pavyzdžiui, „Manau, esu sveikesnis nei dauguma žmonių“)

7) Pasitenkinimo darbu (pavyzdžiui, „Jaučiu pasitenkinimą savo atliekama veikla");

8) Pasitenkinimo gyvenimu Lietuvoje (pavyzdžiui, „Gerai jaučiuosi gyvendamas Lietuvoje").

Lietuviškosios psichologinès gerovès skalès patikimumo koeficientas Cronbacho alfa lygus 0,857 [15]. Šiame tyrime Cronbacho alfa buvo lygi 0,945.

Siekiant nustatyti tiriamuju psichologines charakteristikas, kurios galètu paaiškinti subjektyvios gerovès ịverčius, papildomai pasirinkta Eksternalumointernalumo skalè (E-I), kuri skirta analizuoti žmogaus požiūrị ị ịvairių reiškinių (asmeninių ir neasmeninių) priežastis bei pasekmes [3]. Eksternalumo faktorius vertina tai, kiek individas tiki, kad jo gyvenimo ịvykiai priklauso nuo išorinių veiksnių, kitaip tariant, atsitiktinumų, sẻkmès, likimo, kitų žmonių. Internalumo faktorius vertina tai, kiek asmuo tiki, kad jo gyvenimo įvykiai priklauso nuo vidinių veiksnių, kitaip tariant, nuo jo paties. Metodiką sudaro 30 teiginių, kuriuos prašoma ịvertinti Likerto skalejje nuo atsakymo tikrai ne iki atsakymo tikrai taip. Metodikoje yra 6 subskalès:

1) Globalių įvykių kontrolès (pavyzdžiui, „Žmogaus prigimties nepakeisi, todèl beprasmiška kovoti su įvairiomis blogybèmis");

2) Pasiekimų (karjeros) kontrolès (pavyzdžiui, „Labai dažnai patenku i tokią situaciją, kurioje pasijuntu nieko negalįs pakeisti“");

3) Tarpasmeninių santykių kontrolès (pavyzdžiui, „Kiek kartų buvau susipykęs su kuo nors, vis tai buvo ne dèl mano kaltès");

4) Darbo sèkmès kontrolès (pavyzdžiui, „Egzamino išlaikymas priklauso ne tiek nuo ịdèto darbo, kiek nuo sèkmés"); 
5) Šeimyninių santykių kontrolès, sveikatos kontrolès subskalès (pavyzdžiui, „Tiek yra visokių išorinių veiksnių, kad šeima vaikų auklèjimo klausimu yra bejègë“);

6) Sveikatos kontrolès (pavyzdžiui, „Jeigu likimas lèmė susirgti, tai ir susirgsi“").

Lietuviškosios E-I skalès patikimumo koeficientas Cronbacho alfa lygus 0,75 [3]. Šiame tyrime kontrolès lokuso skalès Cronbacho alfa buvo lygi 0,857 .

İvairių autorių duomenimis, statutinių organizacijų darbuotojų veikla pasižymi itin aukštais streso rodikliais, todèl siekiant išsiaiškinti, kaip subjektyvi gerovè siejasi su streso ịveikimu, buvo panaudotas Streso ịveikos klausimynas [12]. Metodiką sudaro 24 teiginiai, kuriuos prašoma ịvertinti Likerto skalëje nuo atsakymo niekada iki atsakymo visada. Metodikoje yra 4 subskalès:

1) Socialinès paramos (pavyzdžiui, „Kreipiuosi ị tuos, kurie gali mane suprastic);

2) Problemų sprendimo (pavyzdžiui, „Stengiuosi išsiaiškinti, ar probleminès situacijos nesukèlè mano pastangų stoka");

3) Emocinès iškrovos (pavyzdžiui, ,Jaučiu stiprią emocinę įtampą, kurią išreiškiu žodžiais užsipuldamas aplinkinius");

4) Vengimo (pavyzdžiui, „Stengiuosi nukreipti dèmesị nuo problemos ị neutralius arba malonius dalykus").

Streso ịveikos klausimyno socialinès paramos skalès Cronbacho alfa - 0,832, problemų sprendimo $-0,760$, emocinès iškrovos $-0,721$, vengimo $-0,624$ [12] Šiame tyrime bendra streso įveikos skalès Cronbacho alfa buvo lygi 0,525.

Statistiniai duomenys analizuoti naudojant SPSS 19.0 paketą.

\section{Rezultatai}

Siekdami išsiaiškinti statutinių organizacijų darbuotojų procentinị pasiskirstymą pagal subjektyvios gerovès lygius, atlikome gerovès lygio apskaičiavimą bei pritaikème aprašomosios statistikos procedūrą. Iš pateiktų 1 lentelèje rezultatų matome, kad daugiausiai statutinių organizacijų darbuotojai (beveik 46 proc.) pasižymèjo vidutiniu subjektyvios gerovès lygiu.

1 lentele. Statutinių organizacijų darbuotojų pasiskirstymas pagal subjektyvios gerovès lygius

\begin{tabular}{|l|c|c|}
\hline \multicolumn{1}{|c|}{ Lygiai } & Dažnis & Procentai \\
\hline Žema subjektyvi gerovė & 30 & 25,0 \\
\hline Vidutiné subjektyvi gerovė & 55 & 45,8 \\
\hline Aukšta subjektyvi gerovė & 35 & 29,2 \\
\hline
\end{tabular}


Siekdami išsiaiškinti subjektyvios gerovès vertinimus pagal eksternalumo-internalumo faktorius, palyginome tiriamųjų E-I subskalių įverčius pagal subjektyvios gerovès lygius. Rezultatai (2 lentelè) parodè, kad statistiškai patikimai pagal subjektyvios gerovès lygius skiriasi globalių įvykių kontrolès įverčiai $(\mathrm{F}=6,612$, $\mathrm{p}<0,05)$, pasiekimų kontrolès ịverčiai $(\mathrm{F}=18,979, \mathrm{p}<0,05)$, darbo sèkmès kontrolès ịverčiai $(\mathrm{F}=10,910, \mathrm{p}<0,05)$, šeimyninių santykių kontrolès ịverčiai $(\mathrm{F}=12,305, \mathrm{p}<0,05)$ ir sveikatos kontrolès ịverčiai $(\mathrm{F}=4,099, \mathrm{p}<0,05)$.

2 lentelè. Statutinių organizacijų darbuotojų E-I subskalių ịverčių palyginimas pagal subjektyvios gerovès lygius

\begin{tabular}{|c|c|c|c|c|c|c|c|}
\hline E-I subskalès & $\begin{array}{c}\text { Subjek- } \\
\text { tyvios } \\
\text { gerovės } \\
\text { lygiai }\end{array}$ & $\begin{array}{l}\text { Tiria- } \\
\text { mųjų } \\
\text { skai- } \\
\text { čius }\end{array}$ & $\begin{array}{l}\text { Vidur- } \\
\text { kis }\end{array}$ & $\begin{array}{c}\text { Stan- } \\
\text { dar- } \\
\text { tinis } \\
\text { nuo- } \\
\text { krypis }\end{array}$ & $\mathbf{F}$ & df & p \\
\hline \multirow{3}{*}{$\begin{array}{l}\text { Globalių ịvykių } \\
\text { kontrolè }\end{array}$} & Žema & 30 & 37,20 & 6,84 & \multirow{3}{*}{6,612} & \multirow{3}{*}{2} & \multirow{3}{*}{$0,002 *$} \\
\hline & Vidutinè & 55 & 40,78 & 5,16 & & & \\
\hline & Aukšta & 35 & 42,20 & 5,40 & & & \\
\hline \multirow{3}{*}{$\begin{array}{l}\text { Pasiekimų } \\
\text { (karjeros) kontrolè }\end{array}$} & Žema & 30 & 36,53 & 4,17 & \multirow{3}{*}{18,979} & \multirow{3}{*}{2} & \multirow{3}{*}{$<0,001^{*}$} \\
\hline & Vidutinè & 55 & 40,09 & 4,30 & & & \\
\hline & Aukšta & 35 & 43,34 & 4,87 & & & \\
\hline \multirow{3}{*}{$\begin{array}{l}\text { Tarpasmeninių } \\
\text { santykių kontrolè }\end{array}$} & Žema & 30 & 7,73 & 1,87 & \multirow{3}{*}{1,951} & \multirow{3}{*}{2} & \multirow{3}{*}{0,147} \\
\hline & Vidutinè & 55 & 7,91 & 1,70 & & & \\
\hline & Aukšta & 35 & 8,49 & 1,36 & & & \\
\hline \multirow{3}{*}{$\begin{array}{l}\text { Darbo sėkmès } \\
\text { kontrolè }\end{array}$} & Žema & 30 & 14,93 & 3,23 & \multirow{3}{*}{10,910} & \multirow{3}{*}{2} & \multirow{3}{*}{$<0,001^{*}$} \\
\hline & Vidutinè & 55 & 16,84 & 2,32 & & & \\
\hline & Aukšta & 35 & 17,94 & 2,45 & & & \\
\hline \multirow{3}{*}{$\begin{array}{l}\text { Šeimyninių } \\
\text { santykių kontrolè }\end{array}$} & Žema & 30 & 7,07 & 1,60 & \multirow{3}{*}{12,305} & \multirow{3}{*}{2} & \multirow{3}{*}{$<0,001^{*}$} \\
\hline & Vidutinè & 55 & 8,16 & 1,77 & & & \\
\hline & Aukšta & 35 & 9,23 & 1,85 & & & \\
\hline \multirow{3}{*}{ Sveikatos kontrolè } & Žema & 30 & 11,13 & 3,13 & \multirow{3}{*}{4,099} & \multirow{3}{*}{2} & \multirow{3}{*}{$0,019 *$} \\
\hline & Vidutinè & 55 & 11,76 & 2,46 & & & \\
\hline & Aukšta & 35 & 12,94 & 2,39 & & & \\
\hline
\end{tabular}

$* \mathrm{p}<0,05$ F - ANOVA statistikos reikšmè, df - laisvès laipsnių skaičius, $\mathrm{p}$ - statistinis patikimumas

Palyginome statutinių organizacijų darbuotojų streso ịveikos subskalių įverčius pagal psichologinès gerovès lygius. Rezultatai (3 lentelè) parodè, kad pagal psichologinès gerovès lygius statistiškai patikimai skiriasi problemų sprendimo ịverčiai $(\mathrm{F}=7,057, \mathrm{p}<0,05)$ bei emocinès iškrovos ịverčiai $(\mathrm{F}=17,818, \mathrm{p}<0,05)$. 
3 lentele. Statutinių organizacijų darbuotojų streso įveikos subskalių įverčių palyginimas pagal psichologinès gerovès lygius

\begin{tabular}{|c|c|c|c|c|c|c|c|}
\hline & Lygiai & $\begin{array}{l}\text { Tiria- } \\
\text { mųjų } \\
\text { skai- } \\
\text { čius }\end{array}$ & Vidurkis & $\begin{array}{c}\text { Stan- } \\
\text { dar- } \\
\text { tinis } \\
\text { nuo- } \\
\text { krypis }\end{array}$ & $\mathbf{F}$ & df & $\mathbf{p}$ \\
\hline \multirow{3}{*}{$\begin{array}{l}\text { Socialinès } \\
\text { paramos }\end{array}$} & Žema & 30 & 20,20 & 4,02 & \multirow{3}{*}{0,041} & \multirow{3}{*}{2} & \multirow{3}{*}{0,960} \\
\hline & Vidutinè & 55 & 20,00 & 2,665 & & & \\
\hline & Aukšta & 35 & 20,06 & 2,79 & & & \\
\hline \multirow{3}{*}{$\begin{array}{l}\text { Problemų } \\
\text { sprendimo }\end{array}$} & Žema & 30 & 20,33 & 2,82 & \multirow{3}{*}{7,057} & \multirow{3}{*}{2} & \multirow{3}{*}{$0,001 *$} \\
\hline & Vidutinè & 55 & 21,82 & 2,98 & & & \\
\hline & Aukšta & 35 & 23,14 & 3,19 & & & \\
\hline \multirow{3}{*}{$\begin{array}{l}\text { Emocinès } \\
\text { iškrovos }\end{array}$} & Žema & 30 & 16,00 & 3,68 & \multirow{3}{*}{17,818} & \multirow{3}{*}{2} & \multirow{3}{*}{$<0,001^{*}$} \\
\hline & Vidutinė & 55 & 14,60 & 2,27 & & & \\
\hline & Aukšta & 35 & 11,91 & 2,85 & & & \\
\hline \multirow{3}{*}{ Vengimo } & Žema & 30 & 19,80 & 2,98 & \multirow{3}{*}{2,061} & \multirow{3}{*}{2} & \multirow{3}{*}{0,132} \\
\hline & Vidutinè & 55 & 19,33 & 3,85 & & & \\
\hline & Aukšta & 35 & 18,26 & 2,05 & & & \\
\hline
\end{tabular}

*p $<0,05 \quad \mathrm{~F}-$ ANOVA statistikos reikšmè, $\mathrm{df}$ - laisvès laipsnių skaičius, $\mathrm{p}$ - statistinis patikimumas

Siekdami ịvertinti streso ịveikos ir eksternalumo-internalumo (kontrolès lokuso) faktorių reikšmę subjektyviai gerovei, atlikome regresinę analizę. Psichologinė gerovè naudota kaip priklausomas kintamasis, o kontrolès lokusas, streso įveika naudoti kaip nepriklausomi kintamieji. Gautas determinacijos koeficientas $\mathrm{R}^{2}=0,549$ ir ANOVA testo rezultatai $(\mathrm{F}=13,279, \mathrm{p}<0,05)$ parode, kad regresijos modelis yra tinkamas. Iš 4 lentelès matyti, kad tiriamųjų psichologinei gerovei teigiamą reikšmę turi pasiekimų (karjeros) kontrolè $(\mathrm{p}<0,05)$, darbo sẻkmès kontrolè $(\mathrm{p}<0,05)$, o neigiamą reikšmę - emocinè iškrova $(\mathrm{p}<0,05)$.

4 lentelè. Streso ịveikos ir kontrolès lokuso reikšmè subjektyviai gerovei: regresinè analizė

\begin{tabular}{|l|c|c|c|c|}
\hline \multirow{2}{*}{\multicolumn{1}{|c|}{ Kintamieji }} & \multicolumn{2}{|c|}{$\begin{array}{c}\text { Nestandartizuoti } \\
\text { koeficientai }\end{array}$} & \multirow{2}{*}{$\begin{array}{c}\text { Standartizuoti } \\
\text { koeficientai }\end{array}$} & p \\
\cline { 2 - 5 } & B & $\begin{array}{c}\text { Standartizuota } \\
\text { paklaida }\end{array}$ & & \\
\hline Konstanta & 2,598 & 0,569 & & $0,001^{*}$ \\
\hline Pasiekimų (karjeros) kontrolè & 0,040 & 0,011 & 0,387 & $0,001^{*}$ \\
\hline Darbo sėkmės kontrolè & 0,038 & 0,016 & 0,207 & $0,021^{*}$ \\
\hline Emocinès iškrovos & $-0,064$ & 0,014 & $-0,400$ & $0,001^{*}$ \\
\hline
\end{tabular}

$* \mathrm{p}<0,05$ 
Tyrimu taip pat buvo siekiama ịvertinti ryšį tarp statutinių organizacijų darbuotojų subjektyvios gerovės ir streso įveikos. Kaip matome 5 lentelëje, nustatytas teigiamas statistiškai reikšmingas ryšys tarp problemų sprendimo (pastangos spręsti problemas) ir beveik visų psichologinès gerovès subskalių: kuo didesnès pastangos spręsti problemas, tuo aukštesnè subjektyvi gerovè, ir atvirkščiai - kuo didesnè subjektyvi gerovė, tuo didesnès pastangos konstruktyviai spręsti problemas. Taip pat nustatytas vidutinis neigiamas statistiškai reikšmingas ryšys tarp emocinės iškrovos ir visų psichologinès gerovès subskalių: kuo emocinès iškrovos įverčiai aukštesni, tuo psichologinès gerovès ịverčiai yra žemesni, ir atvirkščiai kuo prastesnè subjektyvi gerové, tuo didesnè emocinè iškrova. Be to, nustatytas neigiamas statistiškai reikšmingas ryšys tarp vengimo ir pasitenkinimo pragyvenimo lygiu ịverčių $(r=-0,292, p<0,05)$ bei neigiamo emocingumo įverčių $(r=-0,223$, $\mathrm{p}<0,05$ ): kuo vengimo įverčiai aukštesni, tuo pasitenkinimo pragyvenimo lygiu ir neigiamo emocingumo nebuvimo įverčiai yra žemesni.

5 lentelè. Ryšys tarp statutinių organizacijų darbuotojų subjektyvios gerovès ir streso îveikos: koreliaciné analizè

\begin{tabular}{|c|c|c|c|c|c|}
\hline $\begin{array}{l}\text { Subjektyvios gerovès } \\
\text { skalės }\end{array}$ & & $\begin{array}{l}\text { Socialinès } \\
\text { paramos } \\
\text { ieškojimas }\end{array}$ & $\begin{array}{l}\text { Pastangos } \\
\text { spręsti } \\
\text { problemas }\end{array}$ & $\begin{array}{l}\text { Emocinè } \\
\text { iškrova }\end{array}$ & $\begin{array}{l}\text { Vengimas, } \\
\text { delsimas }\end{array}$ \\
\hline \multirow{2}{*}{ Optimizmas } & $\mathrm{r}$ & $-0,065$ & $0,402^{*}$ & $-0,533^{*}$ & $-0,173$ \\
\hline & $\mathrm{p}$ & 0,482 & $<0,001$ & $<0,001$ & 0,060 \\
\hline \multirow{2}{*}{$\begin{array}{l}\text { Pasitenkinimas } \\
\text { pragyvenimo lygiu }\end{array}$} & $\mathrm{r}$ & 0,078 & 0,025 & $-0,275^{*}$ & $-0,292^{*}$ \\
\hline & $\mathrm{p}$ & 0,397 & 0,786 & 0,002 & 0,001 \\
\hline \multirow{2}{*}{$\begin{array}{l}\text { Neigiamo emocingumo } \\
\text { nebuvimas }\end{array}$} & $\mathrm{r}$ & 0,007 & $0,418^{*}$ & $-0,510^{*}$ & $-0,223^{*}$ \\
\hline & $\mathrm{p}$ & 0,939 & $<0,001$ & $<0,001$ & 0,014 \\
\hline \multirow{2}{*}{$\begin{array}{l}\text { Pasitenkinimas santykiais } \\
\text { su artimaisiais }\end{array}$} & $\mathrm{r}$ & 0,132 & $0,317^{*}$ & $-0,379^{*}$ & $-0,124$ \\
\hline & $\mathrm{p}$ & 0,152 & $<0,001$ & $<0,001$ & 0,178 \\
\hline \multirow{2}{*}{$\begin{array}{l}\text { Pasitenkinimas } \\
\text { tarpasmeniniais santykiais }\end{array}$} & $\mathrm{r}$ & 0,045 & $0,385^{*}$ & $-0,351^{*}$ & $-0,026$ \\
\hline & $\mathrm{p}$ & 0,623 & $<0,001$ & $<0,001$ & 0,780 \\
\hline \multirow{2}{*}{$\begin{array}{l}\text { Pasitenkinimas fizine } \\
\text { sveikata }\end{array}$} & $\mathrm{r}$ & $-0,063$ & $0,442^{*}$ & $-0,503^{*}$ & $-0,154$ \\
\hline & $\mathrm{p}$ & 0,495 & $<0,001$ & $<0,001$ & 0,093 \\
\hline \multirow{2}{*}{ Pasitenkinimas darbu } & $\mathrm{r}$ & 0,019 & $0,386^{*}$ & $-0,501^{*}$ & $-0,124$ \\
\hline & $\mathrm{p}$ & 0,837 & $<0,001$ & $<0,001$ & 0,176 \\
\hline \multirow{2}{*}{$\begin{array}{l}\text { Pasitenkinimas gyvenimu } \\
\text { Lietuvoje }\end{array}$} & $\mathrm{r}$ & 0,079 & $0,248^{*}$ & $-0,323^{*}$ & 0,107 \\
\hline & $\mathrm{p}$ & 0,390 & 0,006 & $<0,001$ & 0,245 \\
\hline
\end{tabular}

$* \mathrm{p}<0,05 \mathrm{r}-$ Pearsono koreliacijos koeficientas, $\mathrm{p}$ - statistinis patikimumas 


\section{Išvados}

Lietuvoje 2014 metais atlikto statutinių organizacijų darbuotojų $(n=120)$ tyrimo rezultatai papildè įvairiose šalyse atliktų tyrimų išvadas apie veiksnius, susijusius su subjektyvia gerove. Tyrimo rezultatai parodé, kad statutinių organizaciju darbuotojų subjektyvi gerovè susijusi su jų ịsitikinimu, jog jie patys atsakingi už savo pasiekimus, karjeros plètojimą, darbo sẻkmę. Tai papildo A. T. Judge (2010) [14] tyrimų rezultatus, patvirtinusius, kad individo kontrolès lokusas gali padèti numatyti subjektyvią gerovę: kuo labiau žmogus jaučiasi galįs kontroliuoti savo gyvenimo sritis ir situacijas, tuo didesnè yra jo subjektyvi gerovè. Šiame tyrime paaiškèjo, kad statutinių darbuotojų subjektyviai gerovei labai svarbus kontrolès jausmas, susijęs su darbo sritimi.

Vienas žymiausių subjektyvios gerovės tyrinètojų Lyubomorsky [16] teigia, kad subjektyvi gerove susijusi su pozityviomis emocijomis ir geresne stresinių situacijų ịveika, ką patvirtino ir šis tyrimas. Statutinių organizacijų darbuotojai, kurie pasižymi didesniais psichologinès gerovès įverčiais, siekdami įveikti stresines situacijas, rečiau ieško kaltụjų, kaltina likimą ar išlieja susikaupusias neigiamas emocijas ant aplinkinių. Esant stresinei situacijai, jie pirmiausiai stengiasi aktyviai ir konstruktyviai susitelkti ị problemos sprendimą, netaiko emocinès iškrovos „bet kam ir bet kada“ strategijos. Statutinių organizacijų darbuotojai, orientuoti i problemų sprendimą, patiria mažiau neigiamų emocijų, pasižymi didesniu optimizmu, pasitenkinimu santykiais su artimaisiais, fizine sveikata, darbu, gyvenimu Lietuvoje. Gauti rezultatai papildo T. W. H. Ng (2006) [18], P. E. Spector (2002) [21], Ž. Šarkauskienès, A. Bagdono (2011) [22] tyrimų išvadas dèl gerovès ir kontrolès lokuso sąsajų, taip pat papildo D. K. Ingledew (1997) [13], C. Biron ir M. KaranikaMurray (2014) [7] tyrimų išvadas dèl subjektyvios gerovès ir streso įveikos sąsajų.

Statutinių organizacijų darbuotojų tyrimu taip pat nustatyta, jog tie darbuotojai, kurie mažiau tiki, kad patys gali kontroliuoti savo gyvenimo situacijas, pasiekimus, šeimos santykius, dažniau ị stresą reaguoja vengimu spręsti iškylančias problemas. Gauti rezultatai sutampa su J. Chen ir C. Silverstone (2008) [8], A. J. Gray- Stanley (2010) [10], L. Meier (2008) [17] požiūriu, jog sèkmingai streso ịveikai būtinas vidinis kontrolès lokusas, tikejjimas savo paties gebejjimu bent iš dalies kontroliuoti gyvenimo aplinkybes.

Siekiant geriau suprasti, kas lemia statutinių organizacijų darbuotojų subjektyvią gerovę, ateityje būtų naudinga atlikti tyrimus su kontroline tiriamųjų grupe, taip pat išnagrinèti objektyvius tiriamujų gyvenimo kokybės veiksnius.

\section{Literatūra}

1. Bagdonas, A.; Kairys, A.; Liniauskaitè, A.; Pakalniškienè, V. Lietuvos gyventoju psichologiné gerove ir jos veiksniai. Vilnius: Vilniaus universiteto leidykla, 2013.

2. Bagdonas, A.; Liniauskaitè, A.; Pakalniškienè, V. Lietuviškoji psichologinès gerovès skale: naudojimo vadovas. Vilnius: Vilniaus universiteto leidykla, 2013. 
3. Bagdonas, A.; Pociūtè, L. Eksternališkumo-internališkumo skalè. Psichologija, 1988, 8, 105-119.

4. Bagdonas, A.; Urbanavičiūtè, I.; Girdzijauskienè, S.; Kairys, A.; Liniauskaitè, A. Lietuviškoji psichologinès gerovès skalè: Struktūros paieškos studentų imtyje. Psichologija, 2012, 45, 22-28.

5. Bandzevičienè, R.; Birbilaitè, S.; Diržytè, A. Kriminalinės policijos pareigūnų stresas, jo ịveika ir vidiné darna. Socialiniu mokslu studijos, 2012, 4(8), 21-37.

6. Baranauskienè, I.; Diržytè, A.; Valaikienè, A. Relation of psychosocial job factors with jobs atisfaction, quality of life, sense of coherence among correctional institution of ficers. Socialiniai tyrimai, 2010, 18, 29-40.

7. Biron, C.; Karanika-Murray, M. Proocess Evaluation for Organizational Stress and Well-Weing Intervention: Implications for Theory, Method and Practice. International Journal of Stress Management, 2014, vol. 21, Nr. 1, 85-111.

8. Chen, J.; Silverthorne, C. The impact of locus of control on job stress, job performance and job satisfactionin Taiwan. Leadership \& Organization Development Journal, 2008, 29(7), 572-582.

9. Diener, E. New findings and future directions for subjectice well-being research. American Psychologist, 2012, 67(8), 590-597.

10. Gray-Stanley, A. J.; Muramatsu, N.; Heller, T.; Hughes, S.; Johnson, T. P.; RamirezValles, J. Work stress and depression among direct support professionals: the role of work support and locus of control. Journal of Intellectual Disability Research, 2010, 54(8), 749-761.

11. Grakauskas, Ž. Stresas ir elgesio savireguliacija: teorinès sąveikos problemos. Psichologija, 2004, 29, 74-87.

12. Grakauskas, Ž.; Valickas G. Streso ịveikos klausimynas: keturių faktorių modelis. Psichologija, 2006, 33, 64-75.

13. Ingledew, D. K.; Hardy, L.; Cooper, L. C. Do resours esbol ster coping and does coping buffer stress? An organizational study with longitud all aspects of control for negative affectivity. Journal of Occupational Health Psychology, 1997, 2(2), 118-133.

14. Judge, A. T.; Kluger, N. A.; Locke, A. E.; Durham, C. C. Dispositional Effects on job and Life Satisfaction: The Role of Core Evaluations. Journal of Applied Psychology, 1998, 83(1), 17-34.

15. Kairys, A.; Bagdonas, A.; Liniauskaitè, A.; Pakalniškienè, V. Lietuvos gyventojų reprezentatyvios imties psichologinès gerovès struktūra. Psichologija, 2013, 48, 7-13.

16. Lyubomorsky, S.; King, J.; Diener, E. The benefits of frequent positive affects: Does happiness lead to success? Psychological Bulletin, 2005, vol. 131, 803-855.

17. Meier, L.; Semmer, N. K.; Elfering, A.; Jacobshagen, N. The Double Meaning of Control: Three-Way Interactions between Internal Resources, Job Control, and Stressors at Work. Journal of Occupational Health Psychology, 2008, vol. 13(3), 244-258.

18. Ng, T. W. H.; Kelly, S. L.; Lillian, E. T. Locusofcontrol at work: a meta- analysis. Journal of Organizational Behaviour, 2006, vol. 27, 1057-1087.

19. Quick, James Campbell, Jonathan D. Nelson, Debra L. Hurrell, Joseph J., Jr. Preventive stress managementin organizations. 1997, 65-88. Washington, DC, US: American Psychological Association, xx, 368 pp. doi: 10.1037/10238-004. 
20. Ruibytė, L. Asmenybės ypatumų ryšys su streso pasekmių vertinimu ir streso ịveikimo pobūdžiu statutinèje organizacijoje. Visuomenès saugumas ir viešoji tvarka. Moksliniu straipsnių rinkinys, 2011, 160-169.

21. Spector, E. P.; Cooper, L. C.; Aguilar-Vafaie, E. M. A Comparative Study of Perceived Job Stressor Sourcesand Job Strainin American and Iranian Managers. Applied psychology: an international rewiev, 2002, 51(3), 446-457.

22. Šarkauskienè, Ž.; Bagdonas, A. Vyresnių klasių mokinių psichologinès gerovės prognostiniai kintamieji. Psichologija, 2011, 44, 7-21.

23. Šilinskas, G.; Žukauskienè, R. Subjektyvios gerovès išgyvenimas ir su juo susiję veiksniai vyrų imtyje. Psichologija, 2004, 30, 47-58.

24. Valickas, G.; Želvienė, P.; Grakauskas, Ž. Patobulinto keturių faktorių streso ịveikos klausimyno psichometriniai rodikliai. Psichologija, 2010, 41, 96-110.

Aistė Diržytė, Aleksandras Patapas, Ustina Fedkovič

\section{Subjective Well-being of Employees of Statutory Organizations}

Abstract

This paper aims to reveal the features of subjective well-being of employees of statutory organizations, as subjective well-being of employees has been identified by many authors to be contributing to work efficiency. In Lithuania, this kind of research has not been carried out before, even though there have been several attempts to analyze subjective well-being of students or medical workers. This article presents a survey $(n=120)$, which was conducted in Lithuania in 2014. The aims of this survey were to find out features of subjective wellbeing of employees of statutory organizations as well as to identify some factors contributing to it. The questionnaire used in this research consisted of several standardized scales: Lithuanian Subjective Well-being Scale (Bagdonas, 2013), Lithuanian Locus of Control Scale (based on the Rotter model, Bagdonas, 1988), Lithuanian Coping with Stress Scale (Valickas, Grakauskas, 2006). The results demonstrated statistically significant relationships between subjective well-being and internal locus of control. It also showed some significant relationships between subjective well-being and coping strategies. However, some additional research is needed to understand better the factors contributing to subjective well-being of employees of statutory organizations.

Aiste Diržytė - Mykolo Romerio universiteto Psichologijos instituto docentè, vyr. mokslo darbuotoja, socialinių mokslų daktarè.

El. paštas: aidir@mruni.eu

Aleksandras Patapas - Mykolo Romerio universiteto Politikos ir vadybos fakulteto Viešojo Administravimo katedros docentas, humanitarinių mokslų daktaras.

El. paštas: patapas@mruni.eu

Ustina Fedkovič - Mykolo Romerio universiteto Teisès psichologijos programos studentė El. paštas: ustinafedkovic@gmail.com

Aistè Diržytè, Doctor of Social Sciences, Mykolas Romeris University, Institute of Psychology, Associated Professor, Chief Researcher.

E-mail: aidir@mruni.eu 
Aleksandras Patapas, Doctor of Humanitarian Sciences, Mykolas Romeris University, Institute of Public Administration, Associated Professor.

E-mail: patapas@mruni.eu

Ustina Fedkovič, Mykolas Romeris University, student of Forensic Psychology Master Program.

E-mail: ustinafedkovic@gmail.com

Straipsnis ịteiktas redakcijai 2014 m. kovo mèn.; recenzuotas; parengtas spaudai 2014 m. gegužès $26 \mathrm{~d}$. 